\title{
Nevralrørsdefekter kan forebygges
}

Norske helsemyndigheter har fra 1998 anbefalt at alle kvinner som planlegger graviditet bør ta folattilskudd 0,4 mg daglig fra siste måned før forventet befruktning og de $2-3$ første månedene av svangerskapet (1). Det er godt dokumentert at folattilskudd forebygger nevralrørsdefekter (2), men også dessverre godt dokumentert at norske kvinner ikke følger myndighetenes råd $(2-5)$. Kvinner med økt risiko for å føde barn med nevralrørsdefekt (brukere av visse antiepileptika eller som har tidligere graviditet med nevralrørsdefekt) er anbefalt folattilskudd med høy dose på $4 \mathrm{mg}$ daglig. Medisinsk fødselsregisters data viser at forekomsten av nevralrørsdefekter i Norge ikke har gått ned siden folatanbefalingene kom i 1998 (6). Riktignok er antall levende barn som fødes med nevralrørsdefekt sterkt synkende siden midten av 1990-årene, til ca. 15 per år, men samtidig er det en økning i antall senaborter, slik at det totale antall svangerskap med nevralrørsdefekter er konstant på 60-70 per år (6).

Dersom alle gravide i Norge hadde fulgt anbefalingene om perikonsepsjonell folatbruk, antar vi at antall svangerskap komplisert med nevralrørsdefekter ville blitt redusert med minst $40 \%$, dvs. med omtrent 30 tilfeller per år (3). En korrekt perikonsepsjonell folatbruk vil virke abortpreventivt ved at færre fostre utvikler en slik misdannelse og færre kvinner da velger provosert abort. Flere friske barn vil kunne fødes og færre barn fødes til et liv med funksjonshemning og store belastninger.

Data fra Norge viser at bare $5-20 \%$ av de gravide i Norge bruker folat i riktig dose og i rett tidsperiode $(4,5)$. Selv gravide med høy risiko for nevralrørsdefekter følger ikke anbefalingene om høy folatdose eller starter i rett tid $(4,5)$. Mange kvinner starter med folat i løpet av svangerskapet, men de aller fleste starter for sent til at folattilskuddet får effekt på nevralrørslukningen. Nevralrøret lukkes innen dag 30 i svangerskapet, dvs. ca. 16 dager etter befruktning. Starter kvinnen med folat etter positiv graviditetstest, er hun sannsynligvis for sent ute til å forebygge nevralrørsdefekter.

Helsemyndighetene har tidligere brukt mange ressurser på å forsøke å nå målgruppen med sine anbefalinger. Slagordet «Forbered barnets helse i din kropp» var sentralt i folatkampanjene fra 1998. Dette budskapet formidles gjennom et bilde av en naken slank kvinne som ser mot sitt eget skyggebilde som gravid (med stor mage) og er uklart i forhold til det som skal formidles: Det er bare folattilskudd perikonsepsjonelt (og kostberiking med folat) som har vist seg å forebygge nevralrørsdefekter. Informasjonen i de statlige kampanjene om sunt kosthold og spising av folatrike matvarer kan virke misvisende, ved at det gis inntrykk av at «naturlig» spising av folatrike matvarer skulle være nok til å forebygge nevralrørsdefekter. Så hvorfor starter ikke gravide kvinner med folat før de blir gravide? Svaret er kanskje enkelt: $50 \%$ av norske kvinner opplyser at de ikke planlegger sin graviditet (3).

Hvilke nye veier kan vi gå i forebyggingsarbeidet? Noen land, slik som USA, har valgt folatberiking av matvarer for å sikre nok folat til den fertile delen av den kvinnelige befolkningen. Denne strategien har ikke norske helsemyndigheter valgt, pga. usikker kostnad-nytteeffekt for resten av befolkningen (utenom fertile kvinner) (2). Antakelig burde målgruppen for folattilskudd utvides, siden mange gravide opplyser at de ikke har planlagt sine svangerskap. Dette betyr at målgruppen bør være alle fertile kvinner (for eksempel 15-45 år). Vi har ingen dokumentasjon på at folatbruk i anbefalt dose til fertile kvinner kan ha skadelige effekter selv om det brukes over lengre tid.

Bruk av moderne informasjonskampanjer rettet mot hele befolkningen ville sannsynligvis ha god effekt, dersom budskapet er enkelt nok. En ny kampanje burde fokusere på tre enkle poeng for gravide og fertile: folat, tobakk og alkohol. Budskapet om at det er viktig å innta folat før man er blitt gravid, burde prioriteres i tillegg til den mer kjente helseinformasjonen om at det er ugunstig med alkohol og tobakk i svangerskapet. Kampanjen burde tilpasses netthverdagen for unge kvinner, ved at sosiale medier som Facebook, Twitter og blogger benyttes. I tillegg burde myndighetene tillate at tabletter med anbefalt dose $0,4 \mathrm{mg}$ folat selges i vanlig butikk, ikke bare gjennom apotek. Merkepåbudet om at tablettene er tiltenkt gravide, bør fjernes. Dette ville kanskje bidra til at flere starter med 0,4 mg tabletter før de blir befruktet, enten befruktningen er planlagt eller ikke. Vi i helsevesenet som har kontakt med fertile kvinner, bør minne dem om folatforebygging, slik som for eksempel ved epilepsikontroller, ved utreisesamtaler fra barselavdelinger eller ved småbarnskontroll på helsestasjoner (mange småbarnsmødre kommer til å få flere barn).

Ryggmargsbrokk- og hydrocephalusforeningen jobber aktivt med å få spørsmålet om folatforebygging av nevralrørsdefekter på dagsordenen igjen (7). Det er på tide at leger og annet helsepersonell i samarbeid med helsemyndighetene og pasientorganisasjonen bidrar til økt oppmerksomhet på en utviklingsdefekt som lar seg forebygge. Det er på tide med nye og effektive opplysningskampanjer. Vår samlede innsats vil kunne bidra til at 30-40 fostre i året ikke utvikler nevralrørsdefekter og at disse svangerskapene dermed ikke ender i senabort eller i fødsel av barn med store helsemessige utfordringer som de gjerne skulle ha sluppet.

\section{Annetine Staff}

Annetine.Staff@oslo-universitetssykeshus.no

Annetine Staff (f. 1962) er overlege ved Oslo universitetssykehus, Kvinneog barneklinikken og professor ved Det medisinske fakultet, Universitetet i Oslo. Hun er medlem av Tidsskriftets redaksjonskomité.

\section{Oppgitte interessekonflikter: Ingen}

\section{Litteratur}

1. Statens ernæringsråd. Anbefalinger og virkemidler for økt folatinntak blant kvinner i fertil alder. Rapport Nr. 1. Oslo: Statens ernæringsråd, 1998.

2. Smeland S, Holven KB, Løken EB et al. Helsemessige gevinster av økt folatinntak? Hvordan nå ut til ønsket målgruppe. Rapport nr 1. IS-1181. Oslo: Nasjonalt råd for ernæring, 2004

3. Staff AC, Løken EB, Holven $\mathrm{K}$ et al. Effekt av offentlige tiltak for å forebygge nevralrørsdefekter. Tidsskr Nor Legeforen 2005; 125: 435-7.

4. Nilsen RM, Vollset SE, Gjessing HK et al. Patterns and predictors of folic acid supplement use among pregnant women: the Norwegian Mother and Child Cohort Study. Am J Clin Nutr 2006: 84: 1134-41.

5. Brække K, Staff AC. Periconceptional use of folic acid supplements in Oslo. Acta Obstet Gynecol Scand 2003; 82: 620-7.

Folkehelseinstituttet. www.fhi.no. (27.1.2011)

7. Ryggmargsbrokk- og hydrocephalusforeningen. Folat på dagsorden. www.ryggmargsbrokk.org/index.cfm?id=312360 (27.1.2011). 